\title{
Comparative Effects of Three Sulfonylureas (Glibenclamide, Glimepiride, and Gliclazide) on Proliferation and Migration of Vascular Smooth Muscle Cells
}

\author{
Rui Zhang ${ }^{a}$ Zhiwei Zou ${ }^{b}$ Xiaojun Zhou ${ }^{a} \quad$ Xue Shen ${ }^{c}$ Zhengyuan Fanc \\ Tianyue $X_{i e}{ }^{c}$ Chunmei $X^{a}{ }^{a} \quad$ Lin Liao $^{a}$ Jianjun Dong ${ }^{b}$ \\ aDivision of Endocrinology, Department of Internal Medicine, Shandong Provincial Qianfoshan \\ Hospital, Shandong University, Jinan, China, bivision of Endocrinology, Department of Internal \\ Medicine, Qilu Hospital of Shandong University, Shandong, China, 'Division of Endocrinology, \\ Department of Internal Medicine, Shandong University of Traditional Chinese Medicine, Jinan, China
}

\section{Key Words}

Diabetes • Sulfonylureas $•$ Restenosis $•$ Vascular smooth muscle cells $•$ ATP-sensitive potassium channel

\begin{abstract}
Background/Aims: Diabetes affects the entire vascular system and accelerates atherosclerosis and ischemia. Percutaneous transluminal angioplasty with or without stenting is the main therapeutic strategies; however, the restenosis rate is high in diabetics. Sulfonylureas (SUs) are widely prescribed agents for the treatment of type 2 diabetes (T2DM) and function by interacting with sulfonylurea receptors (SURs), which also exists in vascular smooth muscle cells (VSMCs), give rise to the potential that SUs influence VSMCs. The proliferation and migration of VSMCs play important roles in the formations of primary stenosis and restenosis, especially the latter. However, there are no data about the exact effects of SUs on these processes. Methods: Human aortic smooth muscle cells (HASMCs) were exposed to SUs prior to exposure to $30 \mathrm{mM}$ glucose. Cell proliferation was detected by CCK8 assay. Cell migration was detected by wound healing assay and transwell assay. Protein expression was determined by immunofluorescence and western blot. Diazoxide was used to evaluate the role of $K_{\text {ATP }}$ channel in these processes. Results: The proliferation and migration of HASMCs were significantly aggravated by glibenclamide and glimepiride, and their effects were reversed by diazoxide. In contrast, above characteristics of HASMCs were apparently inhibited by gliclazide, and this was maintained after opening the $\mathrm{K}_{\text {ATP }}$ channel. Conclusion: These results imply that $\mathrm{K}_{\mathrm{ATP}}$ channels play an important part in proliferation and migration of VSMCs induced by glibenclamide and glimepiride. In contrast, the inhibitory effect of gliclazide on VSMCs appeared to have more potential for the prevention of vascular obstructive diseases in T2DM.

(C) 2019 The Author(s). Published by Cell Physiol Biochem Press GmbH\&Co. KG

Dr. Lin Liao Division of Endocrinology, Department of Internal Medicine, Shandong Provincial and Dr. Jianjun Dong Qianfoshan Hospital, Shandong University, No. 16766, Jingshi Road, Jinan (China) Tel.+86-15168888260, E-Mail liaolin@sdu.edu.cn; dongjianjun@sdu.edu.cn
\end{abstract}




\section{Cellular Physiology Cell Physiol Biochem 2019;52:16-26 \\ \begin{tabular}{ll|l} 
and Biochemistry & DOI: 10.33594/000000002 & Published online: 18 February 2019 \\
Cell Physiol Biochem Press GmbH\&Co. KG
\end{tabular} \\ Zhang et al.: Different Effects of SUs on VSMCs}

\section{Introduction}

Diabetes mellitus affects the entire vascular system and diabetic vascular complications are a major cause of disability and death [1]. Surgical bypass and percutaneous transluminal angioplasty with or without stenting are often recommended [2]. Despite improvement in vascular interventions, the outcome for diabetic patients remains unsatisfactory [3]. Restenosis is still the main limiting factor of the long-term success of vascular intervention therapy, especially in diabetic patients [4].

Sulfonylureas (SUs), which promote insulin release from pancreatic $\beta$-cells by binding to sulfonylurea receptors (SURs) and inhibiting adenosine triphosphate sensitive potassium channels ( $\mathrm{K}_{\text {ATP }}$ channels), are a class of oral antidiabetic drugs most commonly used to treat type 2 diabetes (T2DM)[5]. Prior studies have suggested aggravating or protective effects of SUs on restenosis, which are thought to be associated with insulin secretion and decrease in blood glucose [6]. However, no data about whether distinct effects exist between different sulfonylureas on proliferation and migration of vascular smooth muscle cells (VSMCs) is available. Our previous study showed that, compared with atherosclerosis, excessive migration and proliferation of VSMCs from the arterial media into the sub-endothelial and lumen space have been recognized as primary components in the development of restenosis [7], which is consistent with results obtained in other related studies [8,9]. Moreover, restenotic intimal hyperplasia in diabetics differs from non-diabetics in that diabetic VSMCs exhibit increased rates of proliferation [10]. SURs, the main binding sites for SUs and $\mathrm{K}_{\text {ATP }}$ channel opener, have been identified in VSMCs [11]. Furthermore, several studies have shown that opening of the $\mathrm{K}_{\mathrm{ATP}}$ channel is vasoprotective and could improve hypertension and ischemia [12]. Hence, SUs might impose detrimental effects on the prognosis of vascular intervention, which is a concern in clinical practice.

The objective of this study was to explore the effects of three commonly used SUs (glibenclamide, glimepiride, and gliclazide) on the proliferation and migration of VSMCs and the possible underlying mechanisms. Our results showed that glibenclamide and glimepiride, particularly the former, promote the proliferation and migration of VSMCs. These effects are mediated, at least in part, via closure of $\mathrm{K}_{\text {ATP }}$ channels on VSMCs. In contrast, gliclazide inhibited the proliferation and migration of VSMCs, which is associated with the decreased NF- $\kappa B$ activity.

\section{Materials and Methods}

\section{Cell culture}

Human aortic smooth muscle cells (HASMCs) were incubated in SMCM consisting of $500 \mathrm{~mL}$ of the basal medium, $10 \mathrm{~mL}$ of fetal bovine serum (FBS), $5 \mathrm{~mL}$ smooth muscle cell growth supplement, and $5 \mathrm{~mL}$ penicillin $(100 \mathrm{U} / \mathrm{mL}) /$ streptomycin $(100 \mathrm{ug} / \mathrm{mL})$ solution and maintained at $37{ }^{\circ} \mathrm{C}$ in $5 \% \mathrm{CO}_{2} / 95 \%$ mixed ambient air. HASMC experiments were performed on 5 to 8 passages.

\section{Drugs, antibodies, and reagents}

Glibenclamide, glimepiride, gliclazide and diazoxide (a $\mathrm{K}_{\text {ATP }}$ channel opener) were all purchased from Sigma-Aldrich (St. Louis. MO) and were dissolved in dimethyl sulfoxide (DMSO) and stored at $-80{ }^{\circ} \mathrm{C}$ until use. Solutions of SUs as well as diazoxide were prepared fresh each day. Controls were performed in the presence of appropriate concentration of solvent (DMSO). Unless indicated, the other reagents were from Sigma-Aldrich. Antibodies were obtained from the following sources: anti-SUR2 from Sigma-Aldrich, antip-NF- $\mathrm{BB}-\mathrm{p} 65$ (polyclonal) from Cell Signaling Technology (Beverly, MA), and anti- $\beta$-actin from Proteintech Group (Chicago, IL). All secondary antibodies (polyclonal) were obtained from Jackson ImmunoResearch Laboratories Inc. (West Grove, PA).

To investigate the effects of three SUs (glibenclamide, glimepiride, and gliclazide) on proliferation and migration of VSMCs, HASMCs were treated with these SUs. To further investigate the role of $\mathrm{K}_{\text {ATP }}$ channels in these processes, the HASMCs were treated with $100 \mu \mathrm{M}$ diazoxide prior to exposure to the SUs. 


\section{Cellular Physiology Cell Physiol Biochem 2019;52:16-26 \begin{tabular}{ll|l} 
DOI: 10.33594/000000002 & ( 2019 The Author(s). Published by
\end{tabular} and Biochemistry Published online: 18 February 2019 Cell Physiol Biochem Press GmbH\&Co. KG \\ Zhang et al.: Different Effects of SUs on VSMCs}

Immunofluorescence assay

After fixation with $4 \%$ paraformaldehyde and permeabilization with $0.1 \%$ Triton X-100, cells cultured on glass coverslips were incubated with antibodies against SUR2 (anti-ABCC9, Sigma-Aldrich, 1:100) at $4{ }^{\circ} \mathrm{C}$ overnight, incubated with corresponding Alexa Fluor 555-coupled secondary antibodies (1:200; Invitrogen, Carlsbad, CA) at room temperature for $2 \mathrm{~h}$, and mounted and subjected to examinations under a confocal laser scanning microscope (Fluoview FV1000, Olympus, Japan). Integrated optical intensity (IOD) was calculated by using Image-Pro Plus version 6.0 software (Media Cybernetics, Silver Spring, MD). The mean of the IOD values in the control group was obtained, and the IOD values were normalized to this mean value.

\section{Cell viability assay}

A Cell Counting Kit-8 (CCK8) assay was employed to assess the viability of the cells. The HASMCs were seeded in 96-well plates at a concentration of $5 \times 10^{3}$ cells $/ \mathrm{mL}$ and incubated at $37{ }^{\circ} \mathrm{C}$. Different doses of SUs (glibenclamide, glimepiride, and gliclazide) were added when most cells had attached to the well. After further incubation for 12, 24, $48 \mathrm{~h}$, respectively, cells were washed with phosphate-buffered saline (PBS), and $10 \mu \mathrm{L}$ CCK- 8 solution at $10 \%$ dilution was added. The plate was then incubated at $37{ }^{\circ} \mathrm{C}$ for $1 \mathrm{~h}$ in an incubator. The absorbance at $450 \mathrm{~nm}$ was assayed using a microplate reader (Molecular Devices, Sunnyvale, CA). The means of the optical density (OD) of 3 wells among the indicated groups were used to calculate the percentage of cell viability according to the following formula:

cell viability $(\%)=\left(\mathrm{OD}_{\text {treatment group }} / \mathrm{OD}_{\text {control group }}\right) \times 100$. All experiments were triplicate.

\section{Cell proliferation assay}

The CCK-8 assay was used to detect the effects of SUs on VSMCs proliferation. HASMCs were seeded into a 96-well plate at a density of $5 \times 10^{3}$ cells/well overnight. Cells were then treated with glibenclamide $(21 \mu \mathrm{mol} / \mathrm{L})$, glimepiride $(208 \mu \mathrm{mol} / \mathrm{L})$ or gliclazide $(2000 \mu \mathrm{mol} / \mathrm{L})$ with SMCM for $24 \mathrm{~h}$. Cells were preincubated with diazoxide $(100 \mu \mathrm{mol} / \mathrm{L})$ for $24 \mathrm{~h}$ before the addition of glibenclamide, glimepiride or gliclazide. Cell proliferation was determined using CCK-8 kits (Dojindo Molecular Technologies, Kumamoto, Japan) according to the manufacturer's protocol. Absorbency was measured at $450 \mathrm{~nm}$ by a microplate reader (Thermo Scientific, Millipore, Billerica, MA). The means of the OD of 3 wells among the indicated groups were used to evaluate the change in cell proliferation.

\section{Wound healing assay}

Wound healing tests were conducted on the basis of the protocol of Wang et al. [13], with minor modifications. Briefly, the HASMCs were seeded into six-well plates at a density of $1 \times 10^{5}$ cells per well, and were cultured at $37{ }^{\circ} \mathrm{C}$ with $5 \% \mathrm{CO}_{2}$ until a complete monolayer was formed. A scratch was made in the cell monolayer, and then the medium in the presence or absence of glibenclamide, glimepiride, gliclazide were added. The cells were washed and migration was assessed at 0 or $24 \mathrm{~h}$. The initial and final wound sizes were measured using ImageJ software (National Institutes of Health, Bethesda, MD). Relative migration rate (\%) was calculated on the basis of area of migration.

\section{Transwell assay}

Transwell migration assays were performed using a 24-well Transwell chamber (Corning, NY, USA). Cells were re-suspended in serum-free SMCM at $5 \times 10^{4}$ cells $/ \mathrm{mL}$ and $200 \mu \mathrm{L}$ of cell suspension was added to the upper chamber. SMCM containing $10 \%$ FBS in the presence or absence of glibenclamide, glimepiride, or gliclazide was added into the lower chamber. Diazoxide $(100 \mu \mathrm{M})$ was added before the addition of other drugs. The chamber was incubated for $24 \mathrm{~h}$ at $37^{\circ} \mathrm{C}$. The filter was carefully removed, and cells attached to the upper side were wiped off. Cells migrating through the filter and appearing on the lower side were fixed with $4 \%$ paraformaldehyde for 20 min and stained with 5\% crystal violet. Following washing twice with PBS, the number of migrated cells in three randomly selected visual fields per well was counted under a microscope (Nikon, Tokyo, Japan) for statistical analysis. 


\section{Cellular Physiology Cell Physiol Biochem 2019;52:16-26 \\ \begin{tabular}{ll|l} 
and Biochemistry & DOl: 10.33594/000000002 & $\begin{array}{l}\text { P } 2019 \text { The Author(s). Published by } \\
\text { Published online: } 18 \text { February } 2019 \\
\text { Cell Physiol Biochem Press GmbH\&Co. KG }\end{array}$ \\
\cline { 2 - 3 }
\end{tabular} \\ Zhang et al.: Different Effects of SUs on VSMCs}

Western blotting analysis

Protein isolation and western blot analysis were performed on samples obtained from each group of HASMCs. Protein concentrations in cell extracts were determined (Bio-Rad Laboratories, Hercules, CA). Equal amounts of the protein fractions of lysates were resolved over SDS-PAGE gels and transferred to PVDF membranes. After blocking with 5\% skim milk or bovine serum albumin (BSA), membranes were incubated with primary antibodies. Corresponding secondary antibodies were used. Peroxidase activity was detected by chemiluminescence using and enhanced chemiluminescence detection system. Optical density of the bands was quantified by densitometric analysis using ImageJ software. $\beta$-Actin (\#3700, Cell Signaling Technology) was used as an internal control.

\section{Statistical analysis}

All statistical analyses were performed using Statistical Product and Service Solutions (SPSS) 20.0 software (IBM, Armonk, NY). A Student's $t$-test was used to assess statistical significance of the data within two groups. All data are presented as mean \pm standard error of the mean (SEM). A value of $P<0.05$ was considered statistically significant.

\section{Results}

\section{Determination of SUR2 expression in HASMCS}

Immunofluorescence assays were used to determine the expression of SUR2 in HASMCs and the negative control (Fig. 1A) was used to exclude auto-fluorescence. The results showed that SUR2 was widely expressed in HASMCs (Fig. 1B).
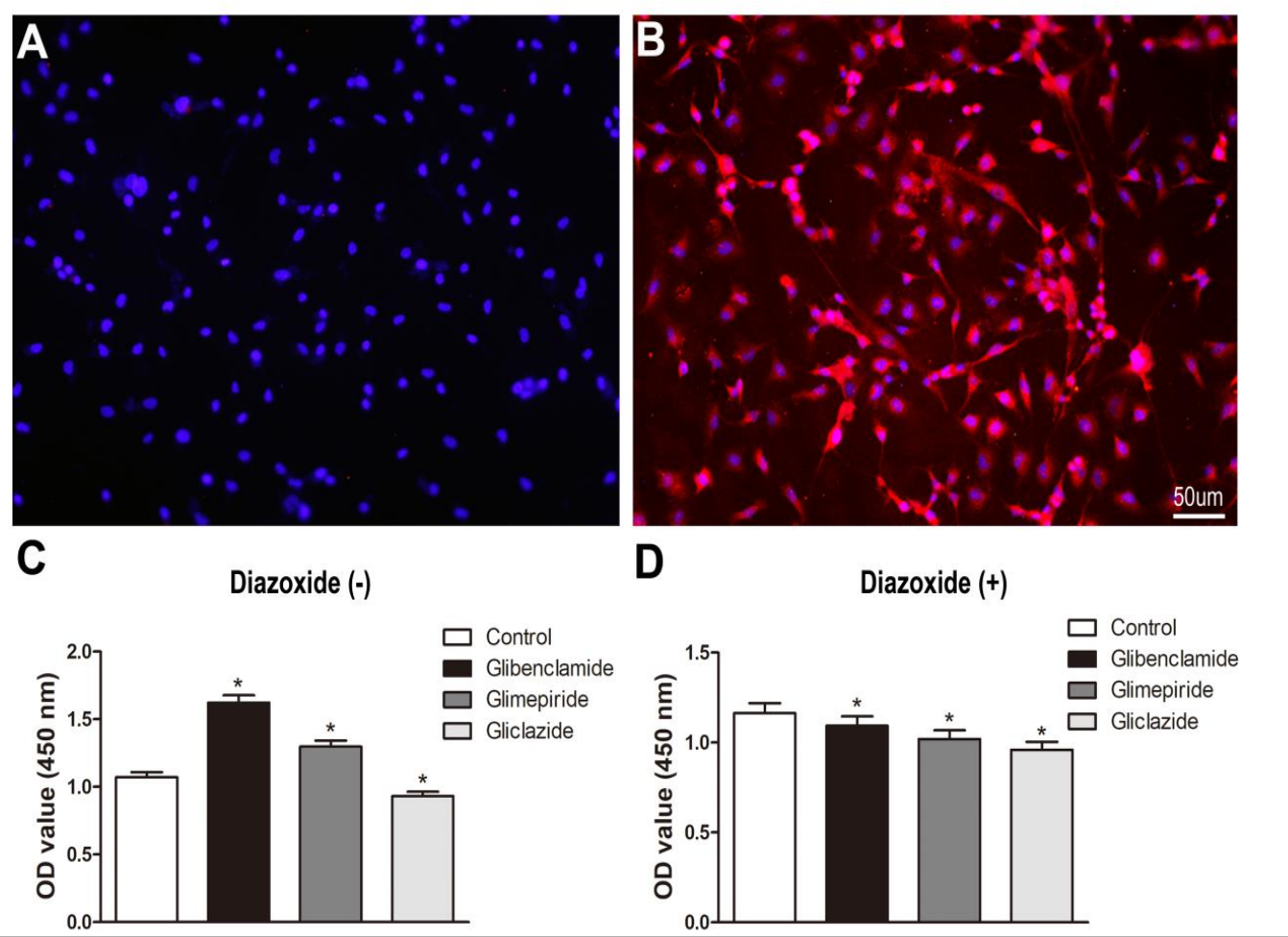

Fig. 1. Expression of SUR2 in VSMCs and effects of diazoxide on SU-induced VSMCs proliferation. The expression of SUR2 in VSMCs was tested by immunofluorescence assay $(\times 200)$. Compared with negative control (A), SUR2 was widely expressed in VSMCs (B). The proliferation of VSMCs in each group was evaluated by CCK-8 assay in the absence (C) or presence (D) of diazoxide, a $\mathrm{K}_{\text {ATP }}$ channel opener. Data are expressed as the mean \pm SEM of triplicate determinations. ${ }^{*} P<0.05$ versus control. 


\section{Effects of SUs on viability of HASMCS}

Our results showed that exposure to SUs led to time and dose-dependent inhibition of cell viability of the HASMCs by CCK-8 assay. HASMCs treated with glibenclamide at concentration of $21 \mu \mathrm{mol} / \mathrm{L}$, glimepiride $208 \mu \mathrm{mol} / \mathrm{L}$, or gliclazide $2000 \mu \mathrm{mol} / \mathrm{L}$ for $24 \mathrm{~h}$ did not significantly affect cell viability. Thus, the above concentrations were used in our following tests.

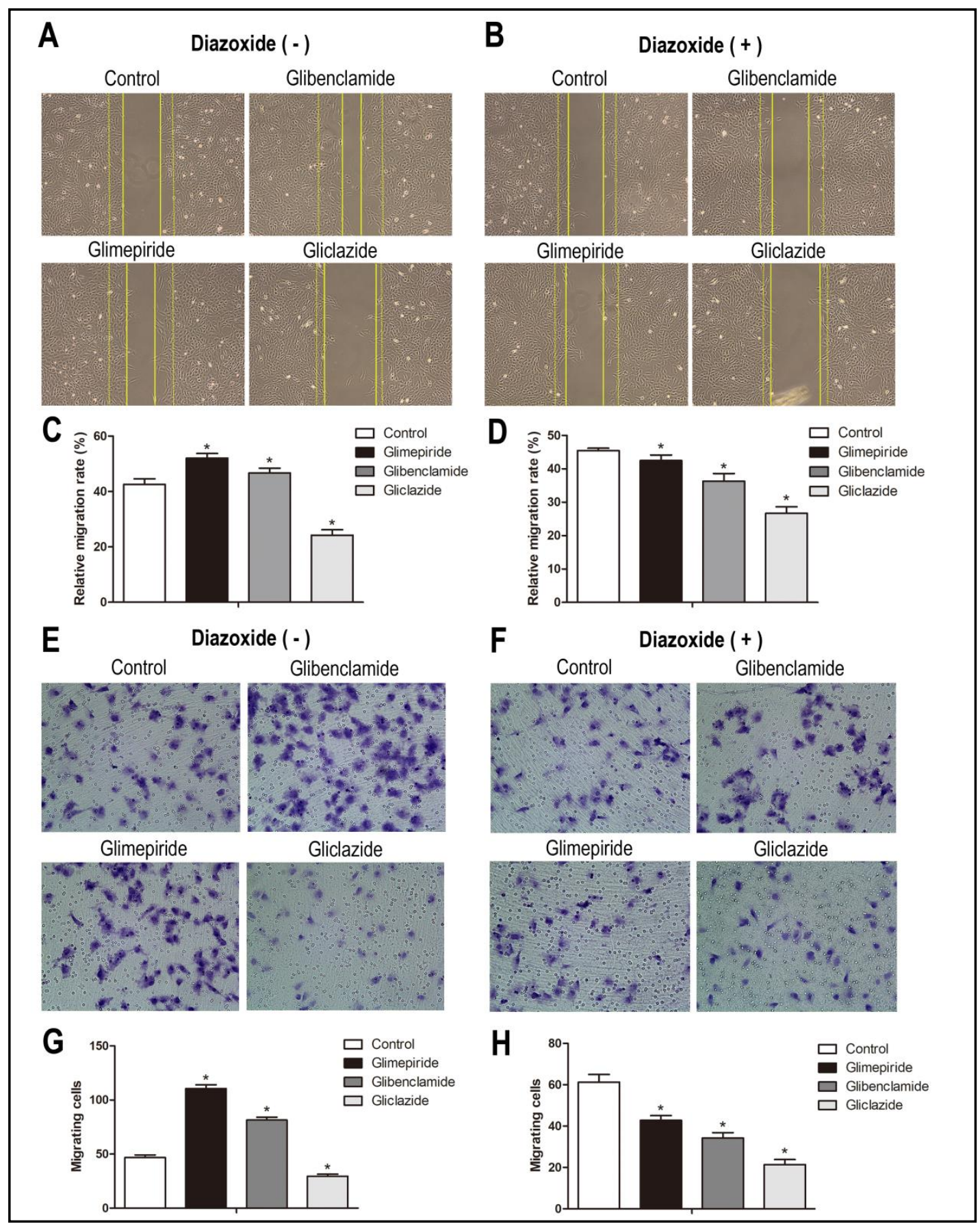

Fig. 2. Effects of diazoxide on SU-induced VSMCs migration. Wound healing assay and transwell assays were used to evaluate the migration of VSMCs in each group in the absence $(A, C, E, G)$ or presence $(B, D, F, H)$ of diazoxide treatment. Data are expressed as the mean \pm SEM of triplicate determinations. $* P<0.05$ versus control. 


\section{Cellular Physiology Cell Physiol Biochem 2019;52:16-26 \\ \begin{tabular}{ll|l} 
and Biochemistry $10.33594 / 000000002$ & C) 2019 The Author(s). Published by \\
Published online: 18 February 2019 & Cell Physiol Biochem Press GmbH\&Co. KG
\end{tabular} \\ Zhang et al.: Different Effects of SUs on VSMCs}

Glibenclamide and glimepiride, rather than gliclazide, promoted proliferation and migration of HASMCs and the above effects were alleviated with $K_{A T P}$ channel opening

To investigate the role of $\mathrm{K}_{\mathrm{ATP}}$ channels in SUs-induced proliferation and migration of smooth muscle cells (SMCs), the HASMCs were treated with or without $100 \mu \mathrm{M}$ of the putative $\mathrm{K}_{\mathrm{ATP}}$ channel opener, diazoxide, for $24 \mathrm{~h}$.

As shown in Fig. 1C and 1D, Glibenclamide and glimepiride, especially the former, significantly promoted the proliferation of VSMCs $(P<0.05$ versus the control group). The above proliferative effects were markedly reversed by diazoxide $(P<0.05)$. However, the effects were different for gliclazide as it significantly inhibited the proliferation of VSMCs $\left(P<0.05\right.$ versus the control group), and was not obviously changed after opening the $\mathrm{K}_{\text {ATP }}$ channels.

Migration is another essential character of VSMCs in stenosis and restenosis. Data from wound healing assays (Fig. $2 \mathrm{~A}$ and $2 \mathrm{C}$ ) and transwell assays (Fig. $2 \mathrm{E}$ and $2 \mathrm{G}$ ) indicated that glibenclamide $(P<0.05)$ and glimepiride $(P<0.05)$ notably stimulated the migration of HASMCs compared with that of control. However, diazoxide significantly suppressed the increased migration induced by glibenclamide and glimepiride $(P<0.05$ versus the control group) (Fig. 2B, 2D, 2F and 2H). In contrast, gliclazide acted differently and it inhibited the migration of HASMCs $(P<0.05$ versus control group) (Fig. 2A, 2C, 2E and 2G). Diazoxide did not significantly influence the gliclazide-induced suppression on the migration of VSMCs (Fig. 2B, 2D, 2F and 2H).

Gliclazide inhibits the proliferation and migration of HASMCs by suppressing $N F-\kappa B$ activation

The limited effect of diazoxide on gliclazide-induced inhibition of the proliferation and migration of VSMCs may be the result of other factors or pathways rather than $\mathrm{K}_{\text {ATP }}$ channel that play major roles in these processes. NF- $\kappa B$ activation has been shown to be involved in the proliferation and migration of VSMCs in response to injury [14]. Research has indicated that gliclazide could inhibit bovine retinal endothelial cell proliferation by interfering with the NF- $\kappa B$ pathway [15]. Our results showed that the expression of p-NF- $\kappa B-p 65$ was reduced and the proliferation and migration of VSMCs were suppressed in the gliclazide-treated group (Fig. 3). To investigate the role of NF- $\kappa B$ in gliclazide-induced inhibitory effect on proliferation and migration of VSMCs, the NF- $\kappa B$ activator, phorbol myristate acetate (PMA), was added into the medium after exposition to gliclazide. As shown in Fig. 3, pretreatment of HASMCs with PMA abrogated the inhibitory effects of gliclazide on VSMCs $(P<0.05)$.

\section{Discussion}

SUs have been reported to not only increase insulin secretion by binding to SUR and blocking $\mathrm{K}_{\text {ATP }}$ channels on $\beta$-cells but also interact with $\mathrm{K}_{\text {ATP }}$ channels in cardiovascular and peripheral vascular system in a similar way thus impairing the ischemic preconditioning and vascular tone [16-18]. However, SUs display differential sensitivity towards different SUR isoforms, and few studies have paid attention to their possible differential influence on the proliferation and migration of VSMCs, the major cells in restenosis progression.

Our results showed that SUR2 is widely expressed in VSMCs. It has been demonstrated that SUR2B/Kir6.1 is the primary functional isoform of $\mathrm{K}_{\mathrm{ATP}}$ channels, which presumably mediates $\mathrm{K}^{+}$transport, in VSMCs [19]. $\mathrm{K}_{\mathrm{ATP}}$ channel activity has been evaluated in numerous cells by its sensitivity to adenosine triphosphate (ATP), SUs and $\mathrm{K}^{+}$-channel openers. Functional $\mathrm{K}_{\text {ATP }}$ channel exist as an octameric complex containing two distinct types of protein subunits. The channels consist of four inwardly rectifying potassium channel subunits (Kir 6.1 or Kir 6.2); each Kir subunit is associated with a larger regulatory SUR [20]. The molecular diversity of the $\mathrm{K}_{\mathrm{ATP}}$ channel across species and tissue types is further expanded by the presence of multiple isoforms of SUR (SUR1, SUR2A and SUR2B) [21]. Different combinations of Kir6.x and SURs yield tissue-specific $\mathrm{K}_{\text {ATP }}$ channel subtypes with different physiological and 


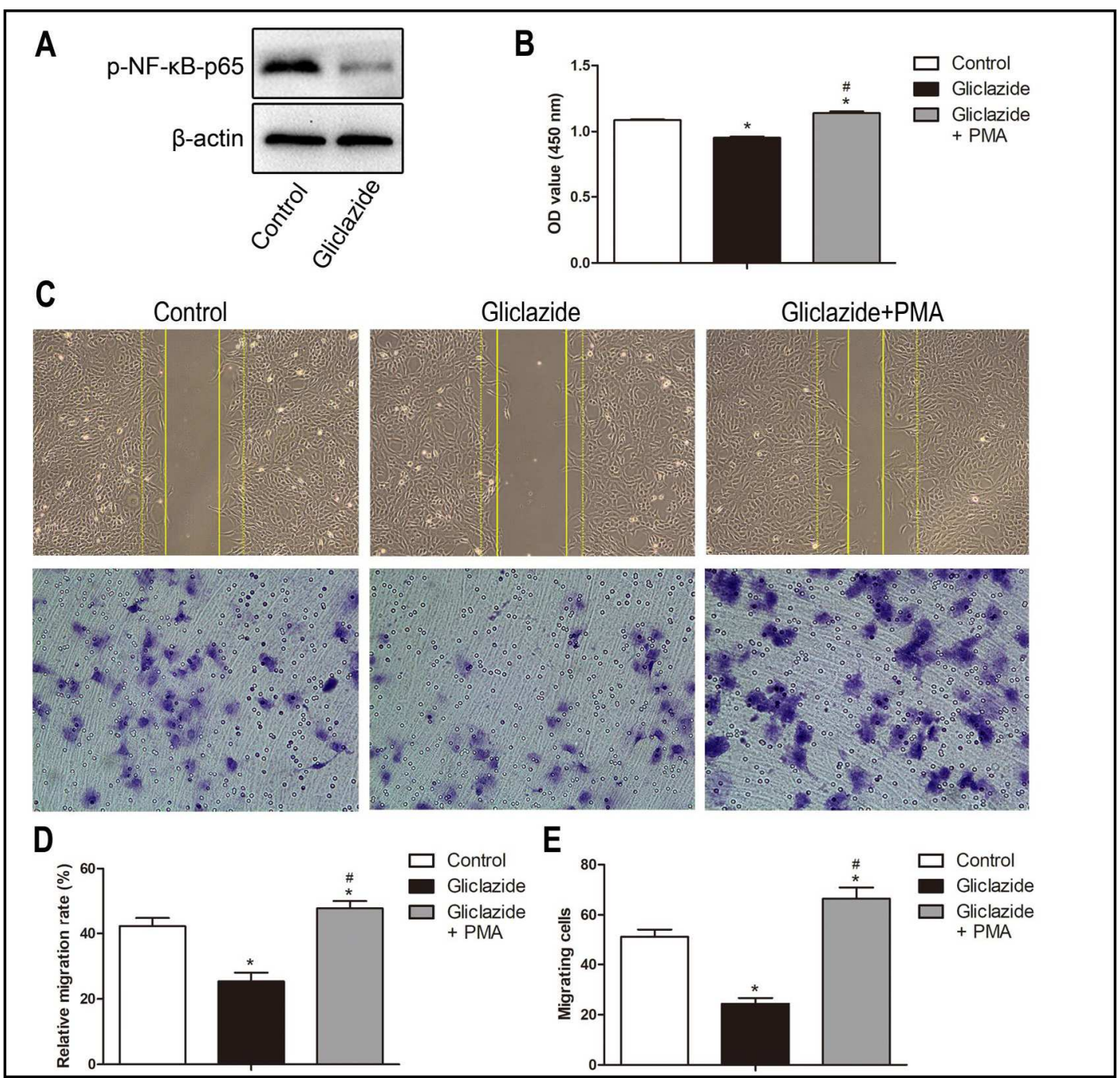

Fig. 3. NF-kB signaling is involved in gliclazide-induced inhibition of VSMCs proliferation and migration. Western blot was used to determine the expression of p-NF-kB (A). CCK8 was used to evaluate proliferation of VSMCs (B). Wound healing assay and transwell assay were used to evaluate the migration of VSMCs (C, $D, E)$. Data are expressed as the mean \pm SEM of triplicate determinations. ${ }^{*} P<0.05$ versus control; \# $P<0.05$ versus gliclazide. PMA is an NF- $\mathrm{\kappa B}$ activator.

pharmacological features $[22,23]$. Serving as an inwardly rectifying $\mathrm{K}^{+}$channel, $\mathrm{K}_{\mathrm{ATP}}$ channels are critical for regulating the resting membrane potential of cells. Closure of $\mathrm{K}_{\text {ATP }}$ channels induced by specific SUs may depolarize the cell membrane, open voltage-dependent $\mathrm{Ca}^{2+}$ channels and increase $\mathrm{Ca}^{2+}$ influx [24]. Like $\mathrm{K}_{\mathrm{ATP}}$ channels in other cells, those of VSMCs are now thought to play vital roles as mediators to a variety of pharmacological and endogenous vasodilators, as well as to changes in the metabolic activity that can directly influence blood flow in various tissues [25]. In addition, Cui et al. showed that the activity of $\mathrm{K}_{\text {ATP }}$ channels appears to be suppressed in proliferating pulmonary arterial smooth muscle cells (PASMCs) [26]. Iptakalim, a novel $\mathrm{K}_{\mathrm{ATP}}$ channel opener, is reported to possess a potent antiproliferative effect on PASMCs and airway smooth muscle cells (ASMCs) via the activation of $\mathrm{K}_{\mathrm{ATP}}$ channels; thus, it is a promising option for treating pulmonary hypertension and chronic airway diseases $[27,28]$. Moreover, the elevation of intracellular $\mathrm{Ca}^{2+}$ induced by the closure of $\mathrm{K}_{\mathrm{ATP}}$ channels is an important regulator of many proliferation and migration factors, which enhance the proliferation and migration of VSMCs [29]. 


\section{Cellular Physiology Cell Physiol Biochem 2019;52:16-26 \\ \begin{tabular}{ll|l} 
and Biochemistry Published online: 18 February 2019 & C 2019 The Author(s). Published by \\
Cell Physiol Biochem Press GmbH\&Co. KG
\end{tabular} \\ Zhang et al.: Different Effects of SUs on VSMCs}

In our research, the proliferation and migration of VSMCs were significantly increased by glibenclamide and glimepiride, especially the former, while they were suppressed by gliclazide. To a certain extent, our results are in agreement with previous observation that glibenclamide and glimepiride, rather than gliclazide, can block the vasodilatation and increase in blood flow induced by diazoxide [30]. Furthermore, Geisen et al. [31, 32] showed that the inhibitory effect of glimepiride on vasodilatation is weaker than that of glibenclamide. As is known, both glibenclamide and glimepiride could combine with SUR2B, the major SUR subtype existing on VSMCs, and closed the $\mathrm{K}_{\mathrm{ATP}}$ channels on the VSMCs. Despite the fact that glibenclamide and glimepiride do not discriminate between SUR1, SUR2A, and SUR2B, they vary in terms of sensitivity and specificity [33,34]. Compared with glibenclamide, glimepiride dissociates quickly from SUR2B, the subunit that modulate the function of $\mathrm{K}_{\text {ATP }}$ channels on VSMCs, and the blockage is reversible [35]. These characteristics of glimepiride might be helpful to gain an understanding of its similar but weaker effects on the proliferation and migration of VSMCs compared with glibenclamide. Additionally, the present study also found that the proliferation and migration of VSMCs induced by glibenclamide and glimepiride could be alleviated or even reversed by a $\mathrm{K}_{\text {ATP }}$ channel opener, implying that closure of $\mathrm{K}_{\text {ATP }}$ channel contributes to the proliferation and migration of VSMCs induced by specific SUs.

In this study, gliclazide, another commonly used SU, showed an inhibitory effect on the proliferation and migration of VSMCs. Previous research has indicated that unlike glibenclamide and glimepiride, gliclazide interacts specially with the SUR1 but not with SUR2A or SUR2B; thus, it produces almost no cross-reactivity with $\mathrm{K}_{\text {ATP }}$ channels in VSMCs [36]. Moreover, in the present study, no significant changes were found before or after treatment with diazoxide in the gliclazide group, which also indicating that $\mathrm{K}_{\text {ATP }}$ channels play a limited role in the gliclazide-induced inhibition of the proliferation and migration of VSMCs. Therefore, factors or pathways other than $\mathrm{K}_{\mathrm{ATP}}$ channels are thought to be involved in these processes. Recent studies have shown that gliclazide, a second generation SU, exerts its insulin-promoting effect by binding with SUR1, which also has an extrapancreatic effect (independent of the interaction with SUR) $[37,38]$. NF- $\kappa B$ is a key player in the expression of inflammatory mediators and plays a crucial role in diabetic cardiovascular complications $[39,40]$. Substantial evidence indicates that activation of the redox-sensitive transcription factor NF- $\kappa \mathrm{B}$ is also implicated in the development of restenosis [41]. On the basis of the free radical scavenging activity of gliclazide and its ability to inhibit NF- $\mathrm{BB}$ activation, it is tempting to postulate that gliclazide may exert these effects by interfering with NF- $\kappa \mathrm{B}-$ dependent signaling pathways. To verify this hypothesis, the NF- $\kappa B$ subunit $\mathrm{p} 65$ were tested in this study. The results showed that activation of NF- $\kappa B$ as well as the stimulatory effects of it on VSMCs was suppressed by gliclazide. In addition, the inhibitory effects of gliclazide on the proliferation and migration of VSMCs were counteracted or even reversed by an NF- $\mathrm{B}$ activator. Herein, our findings suggested that gliclazide-induced NF- $\kappa B$ inactivation might play a vital role in the anti-proliferative and anti-migration effects on VSMCs.

There are a few limitations in this study. First, only three popular SUs (glibenclamide, glimepiride and gliclazide) were included, thus whether our finding could be generalized to other SUs need to be examined in future studies. Second, the potential mechanism of gliclazide in the inhibition of NF- $\kappa \mathrm{B}$ has not yet been elucidated. The differences in the effects among different SUs on VSMCs require further exploration.

\section{Conclusion}

In summary, the major clinical implication of this study relates to the important role of the proliferation and migration of VSMCs in cardio- or peripheral vascular diseases. To the best of our knowledge, this is the first report to confirm that SUs, especially glibenclamide, could promote the proliferation and migration of VSMCs in a $\mathrm{K}_{\mathrm{ATP}}$-dependent manner in high-glucose condition and these effects could be reversed by diazoxide. Whereas, gliclazide showed the opposite effect, it inhibited the proliferation and migration of VSMCs. Thus, SUs 


\section{Cellular Physiology Cell Physiol Biochem 2019;52:16-26 \\ \begin{tabular}{l|l|l}
\hline DOI: 10.33594/000000002 & (c)19 The Author(s). Published by
\end{tabular} \\ \begin{tabular}{l|l} 
Published online: 18 February 2019 & Cell Physiol Biochem Press GmbH\&Co. KG \\
\hline
\end{tabular} \\ Zhang et al.: Different Effects of SUs on VSMCs}

should not be regarded as a homogeneous drug class in terms of their tissue specificity and effects on extrapancreatic cells. Although the clinical relevance of the extra-pancreatic action of SUs is being widely discussed and remains controversial, choosing a highly specific drug with anti-proliferative actions would provide additional potential benefit for people with diabetic vascular diseases and in the treatment of diabetes.

\section{Acknowledgements}

This study is supported by grants from the National Natural Science Foundation of China (81670757, 81770822), Jinan Science \& Technology Development Program, China (201602172), Shandong Provincial Natural Science Foundation, China (ZR2017LH025).

\section{Disclosure Statement}

The authors declare no conflict of interests.

\section{References}

- 1 Wirostko B, Wong TY, Simo R: Vascular endothelial growth factor and diabetic complications. Prog Retin Eye Res 2008;27:608-621.

- 2 Darling JD, McCallum JC, Soden PA, Korepta L, Guzman RJ, Wyers MC, Hamdan AD, Schermerhorn ML: Results for primary bypass versus primary angioplasty/stent for lower extremity chronic limb-threatening ischemia. J Vasc Surg 2017;66:466-475.

- 3 Nicholls SJ, Tuzcu EM, Kalidindi S, Wolski K, Moon KW, Sipahi I, Schoenhagen P, Nissen SE: Effect of diabetes on progression of coronary atherosclerosis and arterial remodeling: a pooled analysis of 5 intravascular ultrasound trials. J Am Coll Cardiol 2008;52:255-262.

4 Baumann F, Ozdoba C, Grochenig E, Diehm N: The Importance of Patency in Patients with Critical Limb Ischemia Undergoing Endovascular Revascularization for Infrapopliteal Arterial Disease. Front Cardiovasc Med 2014;1:17.

5 Canadian Agency for Drugs and Technologies in Health: Glyburide, Gliclazide or Glimepiride for Elderly Patients with Type 2 Diabetes: A Review of the Clinical Effectiveness and Safety - An Update, in: CADTH Rapid Response Reports. Ottawa (ON), 2015.

6 Papanas N, Maltezos E: Oral antidiabetic agents: anti-atherosclerotic properties beyond glucose lowering? Curr Pharm Des 2009;15:3179-3192.

- 7 Zhou X, Dong J, Zhang L, Liu J, Dong X, Yang Q, Liu F, Liao L: Hyperglycemia has no effect on development of restenosis after percutaneous transluminal angioplasty (PTA) in a diabetic rabbit model. J Endocrinol 2015;224:119-125.

> 8 Deuse T, Hua X, Wang D, Maegdefessel L, Heeren J, Scheja L, Bolanos JP, Rakovic A, Spin JM, Stubbendorff M, Ikeno F, Langer F, Zeller T, Schulte-Uentrop L, Stoehr A, Itagaki R, Haddad F, Eschenhagen T, Blankenberg S, Kiefmann R, et al.: Dichloroacetate prevents restenosis in preclinical animal models of vessel injury. Nature 2014;509:641-644.

-9 Hao H, Gabbiani G, Bochaton-Piallat ML: Arterial smooth muscle cell heterogeneity: implications for atherosclerosis and restenosis development. Arterioscler Thromb Vasc Biol 2003;23:1510-1520.

10 Moreno PR, Murcia AM, Palacios IF, Leon MN, Bernardi VH, Fuster V, Fallon JT: Coronary composition and macrophage infiltration in atherectomy specimens from patients with diabetes mellitus. Circulation 2000;102:2180-2184.

11 Yokoshiki H, Sunagawa M, Seki T, Sperelakis N: ATP-sensitive K+ channels in pancreatic, cardiac, and vascular smooth muscle cells. Am J Physiol 1998;274:C25-37.

12 Miura T, Miki T: ATP-sensitive K+ channel openers: old drugs with new clinical benefits for the heart. Curr Vasc Pharmacol 2003;1:251-258. 


\section{Cellular Physiology Cell Physiol Biochem 2019;52:16-26 \begin{tabular}{l|l|l} 
DOI: 10.33594/000000002 & (c)19 The Author(s). Published by
\end{tabular} and Biochemistry Published online: 18 February 2019 Cell Physiol Biochem Press GmbH\&Co. KG \\ Zhang et al.: Different Effects of SUs on VSMCS}

13 Wang G, Mao W, Zheng S: MicroRNA-183 regulates Ezrin expression in lung cancer cells. FEBS Lett 2008;582:3663-3668.

- 14 Bai S, Li D, Zhou Z, Cao J, Xu T, Zhang X, Wang Y, Guo J, Zhang Y: Interleukin-1 Receptor-Associated Kinase $1 / 4$ as a Novel Target for Inhibiting Neointimal Formation After Carotid Balloon Injury. J Atheroscler Thromb 2015;22:1317-1337.

- 15 Mamputu JC, Renier G: Signalling pathways involved in retinal endothelial cell proliferation induced by advanced glycation end products: inhibitory effect of gliclazide. Diabetes Obes Metab 2004;6:95-103.

- 16 Leonard CE, Hennessy S, Han X, Siscovick DS, Flory JH, Deo R: Pro- and Antiarrhythmic Actions of Sulfonylureas: Mechanistic and Clinical Evidence. Trends Endocrinol Metab 2017;28:561-586.

17 Garratt KN, Brady PA, Hassinger NL, Grill DE, Terzic A, Holmes DR, Jr.: Sulfonylurea drugs increase early mortality in patients with diabetes mellitus after direct angioplasty for acute myocardial infarction. J Am Coll Cardiol 1999;33:119-124.

18 Engbersen R, Masereeuw R, van Gestel MA, Siero HL, Moons MM, Smits P, Russel FG: Differential effects of sulfonylurea derivatives on vascular ATP-sensitive potassium channels. Eur J Pharmacol 2012;681:75-79.

19 Suzuki M, Li RA, Miki T, Uemura H, Sakamoto N, Ohmoto-Sekine Y, Tamagawa M, Ogura T, Seino S, Marban E, Nakaya H: Functional roles of cardiac and vascular ATP-sensitive potassium channels clarified by Kir6.2knockout mice. Circ Res 2001;88:570-577.

- 20 Inagaki N, Gonoi T, Clement JPt, Namba N, Inazawa J, Gonzalez G, Aguilar-Bryan L, Seino S, Bryan J: Reconstitution of IKATP: an inward rectifier subunit plus the sulfonylurea receptor. Science 1995;270:1166-1170.

21 Aguilar-Bryan L, Nichols CG, Wechsler SW, Clement JPt, Boyd AE, 3rd, Gonzalez G, Herrera-Sosa H, Nguy $\mathrm{K}$, Bryan J, Nelson DA: Cloning of the beta cell high-affinity sulfonylurea receptor: a regulator of insulin secretion. Science 1995;268:423-426.

22 Inagaki N, Gonoi T, Clement JP, Wang CZ, Aguilar-Bryan L, Bryan J, Seino S: A family of sulfonylurea receptors determines the pharmacological properties of ATP-sensitive K+ channels. Neuron 1996;16:10111017.

23 Yamada M, Isomoto S, Matsumoto S, Kondo C, Shindo T, Horio Y, Kurachi Y: Sulphonylurea receptor 2B and Kir6.1 form a sulphonylurea-sensitive but ATP-insensitive K+ channel. J Physiol 1997;499:715-720.

24 Dufer M, Haspel D, Krippeit-Drews P, Kelm M, Ranta F, Nitschke R, Ullrich S, Aguilar-Bryan L, Bryan J, Drews G: The KATP channel is critical for calcium sequestration into non-ER compartments in mouse pancreatic beta cells. Cell Physiol Biochem 2007;20:65-74.

25 Brayden JE: Functional roles of KATP channels in vascular smooth muscle. Clin Exp Pharmacol Physiol 2002;29:312-316.

26 Cui Y, Tran S, Tinker A, Clapp LH: The molecular composition of K(ATP) channels in human pulmonary artery smooth muscle cells and their modulation by growth. Am J Respir Cell Mol Biol 2002;26:135-143.

- 27 Zhu Y, Zhang S, Xie W, Li Q, Zhou Y, Wang H: Iptakalim inhibited endothelin-1-induced proliferation of human pulmonary arterial smooth muscle cells through the activation of K(ATP) channel. Vascul Pharmacol 2008;48:92-99.

- 28 Liu W, Kong H, Zeng X, Wang J, Wang Z, Yan X, Wang Y, Xie W, Wang H: Iptakalim inhibits PDGF-BB-induced human airway smooth muscle cells proliferation and migration. Exp Cell Res 2015;336:204-210.

29 Chandra A, Angle N: Vascular endothelial growth factor stimulates a novel calcium-signaling pathway in vascular smooth muscle cells. Surgery 2005;138:780-787.

30 Cyrino FZ, Bottino DA, Coelho FC, Ravel D, Bouskela E: Effects of sulfonylureas on K(ATP) channeldependent vasodilation. J Diabetes Complications 2003;17:6-10.

31 Muller G, Satoh Y, Geisen K: Extrapancreatic effects of sulfonylureas--a comparison between glimepiride and conventional sulfonylureas. Diabetes Res Clin Pract 1995;28:S115-137.

32 Geisen K, Vegh A, Krause E, Papp JG: Cardiovascular effects of conventional sulfonylureas and glimepiride. Horm Metab Res 1996;28:496-507.

33 Gribble FM, Tucker SJ, Seino S, Ashcroft FM: Tissue specificity of sulfonylureas: studies on cloned cardiac and beta-cell K(ATP) channels. Diabetes 1998;47:1412-1418.

34 Gribble FM, Reimann F: Differential selectivity of insulin secretagogues: mechanisms, clinical implications, and drug interactions. J Diabetes Complications 2003;17:11-15. 


\section{Cellular Physiology Cell Physiol Biochem 2019;52:16-26 \begin{tabular}{ll|l|l|l}
\hline DOI: 10.33594/000000002 & (C)19 The Author(s). Published by
\end{tabular} \begin{tabular}{l|l} 
Published online: 18 February 2019 & Cell Physiol Biochem Press GmbH\&Co. KG \\
\hline
\end{tabular}}

35 Kakkar R, Ye B, Stoller DA, Smelley M, Shi NQ Galles K, Hadhazy M, Makielski JC, McNally EM: Spontaneous coronary vasospasm in KATP mutant mice arises from a smooth muscle-extrinsic process. Circ Res 2006;98:682-689.

- 36 Seino S, Takahashi H, Takahashi T, Shibasaki T: Treating diabetes today: a matter of selectivity of sulphonylureas. Diabetes Obes Metab 2012;14:9-13.

- 37 Mikov M, Danic M, Pavlovic N, Stanimirov B, Golocorbin-Kon S, Stankov K, Al-Salami H: Potential Applications of Gliclazide in Treating Type 1 Diabetes Mellitus: Formulation with Bile Acids and Probiotics. Eur J Drug Metab Pharmacokinet 2018;43:269-280.

38 Imamur H, Morimoto I, Tanaka Y, Hashimoto O, Kanda K, Yamashita S, Eto S: Regulation of glucose transporter 1 expression by gliclazide in rat L6 myoblasts. Diabetes Nutr Metab 2001;14:308-314.

39 Yin Y, Chen F, Wang W, Wang H, Zhang X: Resolvin D1 inhibits inflammatory response in STZ-induced diabetic retinopathy rats: Possible involvement of NLRP3 inflammasome and NF-kappaB signaling pathway. Mol Vis 2017;23:242-250.

40 Kuo YR, Chien CM, Kuo MJ, Wang FS, Huang EY, Wang CJ: Endothelin-1 Expression Associated with Lipid Peroxidation and Nuclear Factor-kappaB Activation in Type 2 Diabetes Mellitus Patients with Angiopathy and Limb Amputation. Plast Reconstr Surg 2016;137:187e-195e.

- 41 Sun HJ, Zhao MX, Ren XS, Liu TY, Chen Q, Li YH, Kang YM, Wang JJ, Zhu GQ: Salusin-beta Promotes Vascular Smooth Muscle Cell Migration and Intimal Hyperplasia After Vascular Injury via ROS/NFkappaB/MMP-9 Pathway. Antioxid Redox Signal 2016;24:1045-1057. 